\title{
KATOLIČKO STANOVNIŠTVO SELA TOLIŠKE KAPELANIJE ZA VRIJEME „DUBIČKOG RATA“ (1788.-1791.)
}

UDK 314(497.5Tolisa)“1788/1791“

Pregledni rad

Primljeno: 16. 9. 2019.

\begin{abstract}
Ovaj rad predstavlja pokušaj da se na osnovi raspoloživih podataka detaljnije razmotri slučaj preseljavanja katoličkog stanovništva iz srednjeg dijela Bosanske Posavine, tadašnjih sela koja su krajem XVIII. stoljeća pripadala katoličkoj kapelaniji Tolisa, a koje su turske vlasti za vrijeme „Dubičkog rata“ (1788-1791) sistematski preselile u unutrašnjost Bosne, u sjeverna podnožja planina Majevice i Trebave. U radu će se dati odgovori na pitanja: o kojem je broju stanovništva riječ, gdje su konkretno bili preseljeni, kako su bili prihvaćeni od domicilnog stanovništva i kako su prognanici prihvatili tu seobu, kakve su posljedice rata i seobe na ubikaciju današnjih sela Bosanske Posavine te kakvo je kolektivno sjećanje na ovaj događaj. Rad se temelji na crkvenoj arhivskoj građi, pretežno crkvenim maticama i ljetopisima koji se nalaze u franjevačkom samostanu u Tolisi, na starijoj i novijoj literaturi i geografskim, vojnim i katastarskim zemljovidima, terenskom istraživanju i prikupljenim pokretnim nalazima te usmenoj predaji.
\end{abstract}

Ključne riječi: Dubički rat, Bosanska Posavina, preseljenje, Tolisa, Fratrovac, stanovništvo.

\section{Uvod}

Dana 9. veljače 1788. godine Austrija je službeno objavila rat Osmanskom Carstvu. Bio je to posljednji rat koji su ove dvije sile vodile, a Austrija je u njega ušla zbog vojnog sporazuma s Rusijom iz 1781. godine. Rat je vođen duž čitave granice, na istoku u Vlaškoj i Banatu, a na zapadu na krajinskoj „suhoj međi“, oko utvrda Dubica, Novi, Cetingrad i Berbir. Zbog velikih bitki oko grada Dubice ovaj rat se u bosanskohercegovačkoj historiografiji često naziva i Dubičkim ratom. ${ }^{1}$

${ }^{1}$ Galib Šljivo, Bosna i Hercegovina 1788-1812 (Banjaluka: Institut za istoriju u Banjaluci, 1992), 63. 
Ista ta historiografija u stvari se gotovo nikada nije detaljnije bavila problematikom ovoga rata. Najširi njegov opis i događajnicu donosi nam na osnovi austrijskih dokumenata Galib Šljivo u sklopu svoje monografije Bosna $i$ Hercegovina 1788-1812. ${ }^{2}$ Gotovo stotinu godina nakon rata, o njemu je kratku bilješku na dvije stranice ostavio toliški fratar Bono Nedić. ${ }^{3} \mathrm{O}$ stanju pred početak rata izvješće je sastavio austrijski špijun, zastavnik Božić, a objavili su ga Hamdija Kreševljaković i Hamdija Kapidžić. ${ }^{4}$ Događaja se sporadično, bez naročite širine, dotiču i Safvet beg Bašagić i Jako Baltić. ${ }^{5}$ Lokalne monografije hrvatskih posavskih sela, uglavnom pisane od nepovjesničara, mahom su bez kritičke provjere preuzimali podatke iz povijesnog priloga Pave Živkovića prigodničarskoj publikaciji 150 godina osnovne škole u Tolisi pa su na takav način prenijeli i netočnu godinu povratka izbjeglica te još neke sitnije nepreciznosti i anakronosti, na koje ćemo ukazati dalje u tekstu. ${ }^{6} \mathrm{Ni} \mathrm{u}$ pogledu povijesnih izvora stanje ne stoji puno bolje. Jedini je narativni izvor za događaj preseljavanja stanovništva iz Posavine dublje u Bosnu Ljetopis toliškog samostana, no on o ovom događaju govori naknadno, s vremenskim razmakom od nekih pola stoljeća. ${ }^{7}$ Jedini suvremeni i izravni dokumenti su crkvene matične knjige, koje se dijele na knjige krštenih, vjenčanih i umrlih, a koje se u sjevernoj Bosni počinju voditi od sredine 18. stoljeća. Iako one u to vrijeme također imaju narativni, a ne tabelarni oblik kao danas, ipak nam nude standardne, po formuli pisane podatke. Tako nam matična knjiga krštenih, uz ime i prezime krštenika i njegovih roditelja, donosi i mjesto i nadnevak njegovog krštenja, mjesto porijekla roditelja, ime svećenika koji je obred krštenja izvršio te ime i mjesto porijekla krštenikovog kuma ili kume. Matice vjenčanih sadrže podatke o nadnevku i mjestu vjenčanja, imenima, prezimenima i mjestu prebivališta mladenaca i njihovih roditelja, s naznakom ako im roditelji više nisu živi, zatim ime svećenika koji je obred izvršio te imena i prezimena i mjesto prebivališta dvaju ili triju svjedoka na vjenčanju. Matice umrlih sadrže ime i dob umrlog, mjesto i nadnevak smrti, a u nekim slučajevima i uzrok smrti, navode se primljeni sakramenti te mjesto ukopa pokojnika.

\footnotetext{
2 Šljivo, Bosna i Hercegovina 1788-1812, 63-197.

${ }^{3}$ Bono Nedić, Kratka povjest župe, crkve i samostana toliškog, uz pripomoć rukopisah velečastnog o. Martina Nedić-a sastavijo i na svijetlo izdao o. fra Bono Nedić župnik brčanski (Pečuh: Tiskara Mihajla Talzsa, 1887), 13-14.

${ }^{4}$ Hamdija Kreševljaković i Hamdija Kapidžić, Vojno-geografski opis Bosne pred Dubički rat od 1785. godine (Sarajevo: Naučno društvo NR Bosne i Hercegovine 1957).

${ }^{5}$ Safvet beg Bašagić-Redžepašić (Mirza Safvet), Kratka uputa u prošlost Bosne i Hercegovine (Od g. 1463. - 1850.) (Sarajevo: vlastita naklada, 1900), str. 112 o pripremama za ovaj rat kratko piše: „U Bosni su imali zadaću franjevci, da dignu sve kršćane na oružje...“.

${ }^{6}$ Grupa autora, 150 godina osnovne škole u Tolisi (Tolisa: Osnovna škola „Vladimir Nazor“ u Tolisi, 1973), 54-56.

${ }^{7}$ Archiv Samostana Franjevacah u Tolisi od Godine 1885. Knjiga I. (Dalje: Archiv), 19.
} 
Matice župe Bijela te kapelanijā Tramošnica i Tolisa, koje se koriste u ovome radu, do sada su korištene samo za izradu određenih, često i nepreciznih statistika. Njihovo loše stanje očuvanosti, latinski jezik ili hrvatska ćirilica, kojima su matice, ovisno o onom tko ih je vodio, pisane, suvremenim istraživačima odnosile su previše vremena, a donosile malo korisnih podataka. ${ }^{8}$ Međutim, implicitno nam ovi podaci mogu ponuditi puno širu sliku ako ih promatramo u određenom povijesnom kontekstu.

\section{Broj preseljenog stanovništva}

Sjevernu granicu između dva zaraćena carstva, austrijskog i osmanskog, predstavljala je najdužim dijelom rijeka Sava, uz čiju je desnu obalu, koja je pripadala Osmanskom Carstvu, od planine Vučjaka do ušće rijeke Brke, pretežno bilo naseljeno katoličko stanovništvo. Osmanske vlasti, iz straha da ovo stanovništvo u novonastalom ratu ne bi pomagalo svoje istovjerce s druge strane Save, odlučile su sistematski preseliti ih dublje u unutrašnjost Bosne, barem nekoliko sati udaljenosti od same granice.

Teško je reći koliko je bilo preseljenog stanovništva, no uz pomoć nekih onodobnih povijesnih izvora ovaj broj možemo izračunati barem približno. Tolisa je postala kapelanijom u sklopu župe Bijela 1784. godine i taj status će imati do 1802. godine, kada postaje samostalna župa. ${ }^{9}$ Po uspostavi kapelanije pripala su joj sljedeća sela: Tolisa, Donja Mala, Ugljara, Vidovice, Kostrč, Matići, Bok, Oštra Luka, Domaljevac, Grebnice, Škarić i Prud. ${ }^{10}$ Po posljednjem onodobnom sumarnom popisu katoličkog stanovništva u BiH iz 1768 . godine sva pobrojana sela imala su ukupno 1242 stanovnika (706 odraslih). ${ }^{11}$ Oduzmemo li ovom broju broj stanovnika Škarića i Pruda, koji zbog nedostatka izvora neće biti predmet ovog rada, dobijemo 1019 stanovnika u preostalim selima (578 odraslih). Ako ovom broju pridodamo razliku između rođenih i umrlih u narednih 20 godina, dobijemo sljedeće podatke: ${ }^{12}$

${ }^{8}$ Hvale vrijedan je nedavno otkriveni prijepis ovih matica koji je krajem prošloga stoljeća sačinio arheolog-amater (kako se on sam nazivao) Jakov Babić (1928-2016), zaljubljenik u lokalnu povijest porijeklom iz posavskog sela Jagodnjak.

${ }^{9}$ Nedić, Kratka povjest župe, 12, 16.

${ }^{10}$ Nedić, Kratka povjest župe, 13. U Nedićevom popisu sela koja su pripojena kapelaniji Tolisa nalaze se i Kopanice, Jenjić i Vučilovac, međutim mišljenja sam da ta sela, izuzev možda Kopanica, nastaju tek kasnije, što mi dostupne matice i potvrđuju. Prvi spomen Kopanica u maticama je 1795., Jenjića 1801., a Vučilovca 1822. godine. Nedić je, očigledno, podatke preuzeo iz Archiva, str. 19, ali im je anakrono pridodao i ova tri sporna naselja.

${ }^{11}$ Dominik Mandić, Chroati catholici Bosnae et Hercegovinae in descriptionibus annis 1743 et 1768 exaratis (Chicago-Roma, 1962), 204-206.

${ }^{12}$ Treba napomenuti da su ove brojke, iako najbliže do kojih možemo doći, ipak orijentacione i ni u kojem slučaju potpuno precizne. Broj rođenih i umrlih preuzeti su iz matica koje su 
TABLICA 1. Rođeni i umrli u selima toliške kapelanije 1769.-1788. godine

\begin{tabular}{|l|c|c|c|c|c|}
\hline SELO & $\begin{array}{c}\text { STANOVNIKA } \\
\mathbf{1 7 6 8 .}\end{array}$ & $\begin{array}{c}\text { ROĐENIH } \\
\mathbf{1 7 6 9 . - 1 7 8 8 .}\end{array}$ & $\begin{array}{c}\text { UMRLIH } \\
\mathbf{1 7 6 9 . - 1 7 8 8 . ~}\end{array}$ & RAZLIKA & $\begin{array}{c}\text { PRIBLIŽAN BROJ } \\
\text { STANOVNIKA 1788. }\end{array}$ \\
\hline Bok & 118 & 76 & 22 & +54 & $\mathbf{1 7 2}$ \\
\hline Donja Mala & 314 & 183 & 36 & +147 & $\mathbf{5 9 2}$ \\
\hline Domaljevac & 88 & 73 & 10 & +63 & $\mathbf{1 5 1}$ \\
\hline Grebnice & 33 & 33 & 5 & +28 & $\mathbf{6 1}$ \\
\hline Kostrč & - & 35 & 6 & +29 & - \\
\hline Matići & - & 88 & 9 & +79 & - \\
\hline Oštra Luka & 99 & 55 & 7 & +48 & $\mathbf{1 4 7}$ \\
\hline Tolisa & 219 & 155 & 35 & +120 & $\mathbf{3 3 9}$ \\
\hline Ugljara & - & 34 & 11 & +23 & - \\
\hline Vidovice & 148 & 84 & 28 & +56 & $\mathbf{2 0 4}$ \\
\hline UKUPNO & $\mathbf{1 0 1 9}$ & $\mathbf{8 1 6}$ & $\mathbf{1 6 9}$ & $\mathbf{+ 6 4 7}$ & $\mathbf{1 6 6 6}$ \\
\hline
\end{tabular}

Iako ova jednostavna računica pokazuje da su sva sela imala barem trostruko više rođenih nego umrlih u ovom, gotovo dvadesetogodišnjem razdoblju, što bi svakako značilo i povećanje broja kuća, u izvješću zastavnika Božića koji je kroz ove krajeve prošao u rujnu 1785., dakle tri godine prije početka rata, nalazimo neobično mali broj kuća u usporedbi s popisom iz 1768. god. i imajući na umu broj rođenih i umrlih. Naime, Božić za Tolisu kaže da ima oko 15 kršćanskih kuća (na popisu iz 1768. ih je 25), Matići ih imaju 10-12, Domaljevac 5-6 (1768. god. upisano ih je 14). ${ }^{13}$ Također, postoji i austrijska vojna topografska karta iz 1780 . godine ${ }^{14}$ koja obuhvaća i uski pojas južno od

vođene u udaljenoj Bijeloj. Vjerojatno je da jedan dio rođenih i umrlih nije upisan u njih a dio matica nije uopće sačuvan. Tako, na primjer, nedostaju matice krštenih za razdoblje 29. kolovoza 1773. - 27. listopada 1778. godine (6 godina), matice umrlih za razdoblje 8 . travnja 1773. - 13. svibnja 1773. godine (23 upisa) i matice umrlih za razdoblje 7. rujna 1775. - 9. rujna 1776. godine ( 86 upisa). Isto tako ne znamo broj novodoseljenih ili odseljenih, kojih je moralo biti. Na primjer, preci potpisnika ovih redova javljaju se u Boku 1770. godine, gdje su se doselili iz Par Sela kraj Tuzle, dakle iz druge župe, i to vjerojatno nije usamljen slučaj. Potom treba voditi i računa o djevojkama koje su se udale u drugo selo ili čak župu. Nadalje, u tom popisu dosta sela vodi se kao jedno, na primjer Donja Mala, Kostrč, Ugljara, a čini se i Matići, upisani su zajedno kao Utorkovište (tako su i u našoj tablici svedeni pod Donju Malu). Broj rođenih i umrlih u razdoblju 1769. - 1788. god. za Donju Malu, Kostrč, Matiće, Tolisu i Ugljaru preuzeo sam iz prijepisa matica Jakova Babića (rukopis u samostanu u Tolisi), za Oštru Luku iz: Mato Mikičić, Oštra Luka i Bok do početka Domovinskog rata 1992. (Oštra Luka, 1994), 33-34, za Vidovice iz: Marko Babić, Župa Vidovice (Vidovice-Zagreb: Fonticulus Vidovicensis i Župni ured sv. Vida - Vidovice, 2003), 339-349, 351-352.

${ }^{13}$ Kreševljaković i Kapidžić, Vojno-geografski opis Bosne, 63, 66.

${ }^{14}$ Karta dostupna na: https://mapire.eu/en/map/firstsurvey-slavonia-mf/?layers=osm\%2C156\&b box $=2069561.4981666785 \% 2 \mathrm{C} 5627868.019279433 \% 2 \mathrm{C} 2082450.6920612664 \% 2 \mathrm{C} 5631689$. 870693693 (pristupljeno 12. 07. 2019). 
Save, ali mi se ne čini pouzdanom jer na njoj Tolisa i Ugljara imaju isti broj ucrtanih kuća (po devet), Domaljevac ih ima deset, a Utorkovište dvanaest, što bi unekoliko i odgovaralo Božićevom izvješću, ali ne i crkvenim maticama, koje ipak smatram pouzdanijim izvorom. Naravno, postoji mogućnost da se izvjestan broj stanovništva odselio, kao što je bio slučaj i za vrijeme Dubičkog rata, kada je jedan dio pobjegao preko Save u Babinu Gredu, Štitar, Županju i Bošnjake, gdje su mnogi imali rodbinu, ali to i dalje ne opravdava ovako veliku razliku glede broja kuća koju nam donose ova dva izvora. Zapovjedništvo austrijske Slavonske vojne krajine u načelu nije dozvoljavalo masovne i stihijske prijelaze preko Save, mada je pojedinačnih slučajeva svakako bilo. ${ }^{15}$ Razmatrao sam i mogućnost o velikim obiteljskim zadrugama gdje je više obitelji živjelo u jednoj kući. Dvadeset i dvije osobe po kući (što bi, ako tako uzmemo, bio prosjek za Tolisu u ovom razdoblju) nije neuobičajeno kao izuzetak, ali jeste kao pravilo. Na koncu, vjerujem da je odgovor na ovo pitanje puno kompleksniji nego što nam ga u ovome trenutku mogu ponuditi raspoloživi povijesni izvori.

Po svoj prilici ovo prinudno preseljavanje izvršeno je, uprkos zimi, snijegu i niskim temperaturama, ${ }^{16}$ brzo i nasilno, i to nedugo nakon objave rata. Sudeći po matici vjenčanih za ovu godinu, još 3. veljače Posavci su bili u svojim domovima. Tog dana sklopljena su tri braka: u Tolisi, Kostrču i Boku. ${ }^{17} \mathrm{Na}$ žalost, matica krštenih ove kapelanije, koja bi trebala predstavljati najznačajniji izvor jer je najažurnije vođena, za ovu godinu ima samo 11 upisa, vremenski i prostorno raštrkanih. ${ }^{18}$ No, nota ${ }^{19}$ koja stoji upisana u sve tri matice obavještava nas da su kršteni, vjenčani i umrli ove kapelanije tijekom četvorogodišnjeg rata bili upisivani u matice župe Dubrave (Bijela) i kapelanije Tramošnica. I doista, već 12. ožujka 1788. godine, Mato Mišković iz Kostrča je u Turiću krstio kćer Luciju, ${ }^{20}$ iz čega možemo zaključiti da su katolici iz sela uz Savu već tad bili raspoređeni pod sjeverne obronke planina. Da je preseljenje bilo nasilno govore nam dva upisa iz tramošničke matice umrlih

${ }^{15}$ Damir Matanović, „Sava u svakodnevnom životu krajišnika Slavonske vojne krajine“, u: Rijeka Sava u povijesti - Zbornik radova znanstvenog skupa održanog u Slavonskom Brodu 18-19 listopada 2013., uredio Branko Ostajmer, (Slavonski Brod: Hrvatski institut za povijest - Podružnica za povijest Slavonije, Srijema i Baranje, 2015), 251-259.

16 Šljivo, Bosna i Hercegovina 1788-1812, 63.

${ }_{17} \mathrm{MVK} /$ ŽT 1784-1832, 57-59/1788.

${ }^{18}$ Kao mjesta odakle su roditelji spominju se: Škarić, Špionica, Dubrave, Utorkovišta, Vidovice, Poljaci i Skakava.

${ }^{19} \mathrm{U}$ matici vjenčanih, nakon r. br. 60: „Notandum: qvod per qvartuor ferme Annos nempe tempore Belli: Copulati adscripti sunt aligvi in Libro Parochiali Dubravis de hoc Capellania Tolisenssi; aliqvi vero in Libro Capellaniae de Tromosnicza“. Slično i u matici krštenih nakon r. br. 199 .

${ }^{20} \mathrm{MKK} / Z \breve{T r}$ 1784-1805, 218/1788. 
od 15. travnja 1788. godine, kada su u praznom Miloševcu Turci zatekli i ubili Pavu Varljića i Matu Vukadina iz Garevca. ${ }^{21}$ Zbog nekih prijestupa koji se ne navode, kadije su na smrt vješanjem osudile tridesetogodišnjeg Josu Đordića iz Boka. Kazna je izvršena 1. lipnja 1790. godine. ${ }^{22}$ Fra Jako Baltić u svome Godišnjaku od događaja i promine vrimena u Bosni piše za 1788. godinu: „Ove godine velika nevolja i progonstvo za krstjane bi od turaka $(\ldots)^{“}{ }^{23}$ A kako je izgledala ta stihijska selidba, opisuje fra Bono Nedić: „,Na brzu ruku što se je moglo potjerati, povući i ponieti to se je sabralo i priselilo u Blaževac ili pravije izmedju selah Blaževac i Četnice župe Bijele i tude se privremeno naseliše (...) Mnogi nadajući se da će se brzo povratiti zakopaše kazane i drugi bakar u zemlji koji u njoj ostadoše jer pune četiri godine iseljenici ostadoše u Fratrovcu (... “. ${ }^{24}$

\section{Smještaj prognanika u podmajevička i podtrebavska sela}

Fratrovac (ili, kako u maticama ponekad stoji - Fratrović) je predio između Blaževca i Porebrica koji se i dan-danas tako naziva. Ime je dobio po fra Jakobu Paradžikoviću, koji je bio toliški kapelan i koji se skupa sa svojim pukom povukao dublje na jug tijekom ove selidbe. Ovdje su naseljeni isključivo Tolišani i jedan dio Vidovljana. Ostali Vidovljani bili su raštrkani po Donjoj Skakavi, Blaževcu i Dubravama, odnosno zaseocima Bubanj i Barani, što su možda današnje Podbare na putu od blaževačkog groblja prema crkvi u Poljacima. U ova zadnja četiri mjesta, Blaževac, Dubrave, Barani i Bubanj, bili su naseljeni i Mahalci, dok se Ugljarci spominju isključivo u Dubravama. Domlječani su manjim dijelom bili u Donjim Hrgovima, a većim dijelom u Tramošnici. Zadnje godine progonstva spominju se i u Batkuši, isto kao i Lučani, koji su najviše raseljeni u Tramošnicu. Stanovnici Matića i Kostrča boravili su u Turiću, a Bočani su bili u Tramošnici, Orlovom Polju i nekom mjestu imena Čelara, za koje nisam uspio odrediti gdje se nalazilo. ${ }^{25}$

${ }^{21}$ MUK/ŽTr 1784-1827, 98 i 99/1788.

${ }^{22} \mathrm{MUK} / \mathrm{Z} \operatorname{Tr} 1784-1827,174 / 1790$.

${ }^{23}$ Jako Baltić, Godišnjak od događaja i promine vrimena u Bosni 1754-1882. (Sarajevo-Zagreb: Synopsis, 2003), 101.

${ }^{24}$ Prema: Stanko Mijić, Vremeplov Bosanske Posavine - Crkva i samostan na Raščici (Tolisa: Franjevački samostan u Tolisi, 2002), 126-127.

${ }_{25}$ Jakov Babić, rukopisna ostavština, bilježnica Ia: prijepis matica 1742-1784, stranice numerirane rukom 193-310, str. 295-310. 


\section{Boravak u progonstvu: odnos s domicilnim stanovništvom, broj rođenih i umrlih prognanika}

Čini se da su pridošlice bile dobro prihvaćene od domicilnog stanovništva. Tako, recimo, Bočani već u prvoj godini progonstva sklapaju kumstva, birajući kumove svojoj djeci među domaćim stanovništvom, ali i sami kumujući djeci iz Tramošnice i Turića. ${ }^{26}$ Neke djevojke se čak i udaju za momke iz Turića i Tramošnice. ${ }^{27} \mathrm{U}$ duhu kršćanskog zajedništva i umrli prognanici se ukapaju u općinska groblja u Dubravama i Okrugliću s ostalim, domaćim stanovništvom. ${ }^{28}$ Po računici Jakova Babića koju je radio uz pomoć matica krštenih i umrlih, u progonstvu je za ove četiri godine rođeno 217 djece, od čega 135 u selima oko Dubrava, a 82 u selima koja su pripadala tramošničkoj kapelaniji. Izračunao je da su u istom ovom razdoblju u progonstvu umrle 102 osobe, u Dubravama i okolici 85, a 17 u Tramošnici i okolnim selima. ${ }^{29}$ Brojka koju sam ja dobio vadeći podatke iz dubravačkih matica ${ }^{30}$ je 134 rođenih i 81 umrlih, a iz tramošničkih matica je 89 rođenih i 29 umrlih, što daje cjelokupnu brojku od 223 rođenih i 110 umrlih stanovnika toliške kapelanije u progonstvu.

TABLICA 2a. Rođeni i umrli stanovnici sela toliške kapelanije u progonstvu u okolici Dubrava 1788.-1791. godine.

\begin{tabular}{|l|c|c|c|c|c|c|c|c|c|c|}
\hline \multirow{2}{*}{ SELO } & $\mathbf{1 7 8 8}$ & \multicolumn{2}{|c|}{$\mathbf{1 7 8 9 .}$} & \multicolumn{2}{c|}{$\mathbf{1 7 9 0 .}$} & \multicolumn{2}{|c|}{1791.} & \multicolumn{2}{c|}{ UKUPNO } \\
\cline { 2 - 12 } & $\mathbf{R}$ & $\mathbf{U}$ & $\mathbf{R}$ & $\mathbf{U}$ & $\mathbf{R}$ & $\mathbf{U}$ & $\mathbf{R}$ & $\mathbf{U}$ & $\mathbf{R}$ & $\mathbf{U}$ \\
\hline Domaljevac & 1 & - & 1 & - & 1 & - & 2 & - & $\mathbf{5}$ & - \\
\hline Donja Mala & 8 & 1 & 7 & 8 & 17 & 8 & 15 & 7 & $\mathbf{4 7}$ & $\mathbf{2 4}$ \\
\hline Tolisa & 10 & 17 & 7 & 12 & 16 & 3 & 6 & 6 & $\mathbf{3 9}$ & $\mathbf{3 8}$ \\
\hline Ugljara & 3 & 1 & 1 & - & 3 & 2 & - & 2 & $\mathbf{7}$ & $\mathbf{5}$ \\
\hline Vidovice & 7 & 5 & 6 & 2 & 14 & 4 & 9 & 3 & $\mathbf{3 6}$ & $\mathbf{1 4}$ \\
\hline UKUPNO
\end{tabular}

${ }^{26}$ MKK/ŽTr 1784-1805, 223/1788, 269/1788.

${ }^{27}$ MVK/ŽTr 1784-1831, 71/1788.

${ }^{28}$ Babić, rukopisna ostavština, str. 301-304, 307, 310.

${ }^{29}$ Babić, rukopisna ostavština, str. 310.

${ }^{30}$ Kako su mi dubravačke matice za ovo razdoblje ostale nedostupne, računicu sam radio po prijepisu Jakova Babića. Brojke nam se ne podudaraju jer je Babić brojao i upise obitelji koje se nakon završetka rata nisu vratile na svoja ognjišta, nego su ostale nastanjene oko Bijele i Tramošnice. 
TABLICA 2b. Rođeni i umrli stanovnici sela toliške kapelanije u progonstvu u okolici Tramošnice 1788.-1791. godine.

\begin{tabular}{|l|c|c|c|c|c|c|c|c|c|c|}
\hline \multirow{2}{*}{ SELO } & \multicolumn{2}{|c|}{$\mathbf{1 7 8 8}$} & \multicolumn{2}{c|}{$\mathbf{1 7 8 9 .}$} & \multicolumn{2}{c|}{$\mathbf{1 7 9 0 .}$} & \multicolumn{2}{|c|}{$\mathbf{1 7 9 1 .}$} & \multicolumn{2}{c|}{ UKUPNO } \\
\cline { 2 - 12 } & $\mathbf{R}$ & $\mathbf{U}$ & $\mathbf{R}$ & $\mathbf{U}$ & $\mathbf{R}$ & $\mathbf{U}$ & $\mathbf{R}$ & $\mathbf{U}$ & $\mathbf{R}$ & $\mathbf{U}$ \\
\hline Bok & 5 & - & 3 & - & 6 & 4 & 7 & 3 & $\mathbf{2 1}$ & $\mathbf{7}$ \\
\hline Domaljevac & 2 & 1 & 7 & 2 & 7 & 6 & 2 & 1 & $\mathbf{1 8}$ & $\mathbf{1 0}$ \\
\hline Kostrč & 2 & - & 1 & - & 1 & - & 2 & - & $\mathbf{6}$ & - \\
\hline Matići & 4 & 5 & 6 & 1 & 10 & - & 7 & 1 & $\mathbf{2 7}$ & $\mathbf{7}$ \\
\hline Oštra Luka & 4 & 1 & 1 & - & 6 & 4 & 5 & - & $\mathbf{1 6}$ & $\mathbf{5}$ \\
\hline Vidovice & 1 & - & - & - & - & - & - & - & $\mathbf{1}$ & - \\
\hline UKUPNO & \multicolumn{9}{|c|}{} \\
\hline
\end{tabular}

\section{Završetak rata i povratak prognanika u Posavinu}

Što se tiče samog rata koji je trajao, ne znamo jesu li njime bila zahvaćena i područja toliškog kraja. Poznato je da je do jednog žešćeg okršaja došlo kod Šamca kada je u noći između 10. i 11. srpnja 1788. godine oko 1500 ljudi pod zapovjedništvom gradačačkog kapetana pokušalo upasti na hrvatsku stranu. U boju koji je započeo u četiri sata ujutro i trajao 11 sati napadači su izgubili oko 30 ljudi i imali veliki broj ranjenih. ${ }^{31}$ Fra Bono Nedić pisao je da se neki žestok boj odigrao i na Topolovcu, polju uz Savu koje je ležalo sjeverno od mjesta gdje se u to vrijeme nalazilo selo Tolisa. On to mišljenje temelji na tome što se u njegovo vrijeme na tom polju moglo naći trulog oružja - pušaka i sablji, ${ }^{32}$ no ovo je moglo biti i oružje iz nekog kasnijeg razdoblja, možda iz nekog od ustanaka kojima je obilovalo XIX. stoljeće. Ovaj rat, posljednji koji su Austrija i Osmansko Carstvo vodili u svojoj povijesti, zaključen je mirom u Svištovu, 4. kolovoza 1791. godine, a njegova glavna odredba bila je da se granice između dvaju carstava vrate na prijeratno stanje, uz neke neznatne promjene. ${ }^{33}$ Nedugo nakon sklapanja mira počeo je i povratak stanovništva u sela oko Tolise. Već u kolovozu ove godine neki Bočani su se vratili iz progonstva te ih u tramošničkim maticama više ne nalazimo upisane kao iz Tramošnice, Orlova Polja i Čelara, već, u dva upisa, kao iz Boka. ${ }^{34}$ Moguće stoga što u Tolisi još uvijek nije bilo kapelana, pa je djecu i dalje krstio onaj tramošnički. Isto tako, u dubravačkim i tramošničkim maticama umrlih od kraja kolovoza nema više niti jednog upisa nekoga iz sela toliške kapelanije. I

\footnotetext{
${ }_{31}$ Šljivo, Bosna i Hercegovina 1788-1812, 87.

32 Prema: Mijić, Vremeplov Bosanske Posavine, 127.

33 Šljivo, Bosna i Hercegovina 1788-1812, 176-177.

${ }^{34}$ MKK/ŽTr 1784-1805, 577/1791, 591/1791.
} 
fra Bono Nedić piše da su se prognanici vratili „,na svrhi četvrte godine“. ${ }^{35}$ Već od druge polovine siječnja 1792. godine ${ }^{36}$ počinju se voditi i toliške matice s novim kapelanom, fra Ambrožom Vučkovićem, koji je do tada, sve godine rata, bio župnikom u Bijeloj. ${ }^{37}$

\section{Promjena lokacija pojedinih sela}

Međutim, jedan dio prognanika nije se po povratku htio naseliti na svoja stara ognjišta. Tolišani, Doljanci, Bočani i Vidovljani, a možda i Kostrčani, osnovali su svoja sela na novim lokacijama. Tolisa, koja se nalazila s desne strane istoimene rijeke, gotovo na njenom ušću, ${ }^{38}$ pomaknuta je oko kilometar i pol (fra Bono kaže za jedan četvrt sahata) jugoistočno i u centru sela podignuta je kuća za župnika, na čijem mjestu i danas stoji spomen-križ. ${ }^{39}$ Na mjestu starog sela, na njivama koje nose naziv Kućišta, podignut je 1976. godine spomen-bunar (nalazi se uz zapadni rub njive upisane pod k. č. 2747), dok tradicija govori da je župnikova kuća (narod kaže: stara crkva) bila dvjestotinjak metara zapadnije od spomen bunara (otprilike na međi k. č. 2853 i 2854). Fra Bono piše da su Tolišani vrativši se kućama zatekli zgarišta i da su zbog toga odabrali novo mjesto za podignuti naselje. Autor ovoga teksta je nekoliko puta izlazio na teren i u tom prostoru nije uspio pronaći tragove koji bi sugerirali da je na tom mjestu bilo nekakvo naselje koje je spaljeno, dok pokretni nalazi odaju sasvim drugačiji kontekst, ukazujući na naselje iz puno ranijeg razdoblja. Pokretnih nalaza iz 18. stoljeća je jako malo; pronađena su tek dva novčića iz 1745. godine u apoenima od 2 i 3 krajcara te poklopac lijeka ,theriaca“, ali on bi mogao biti i iz nekog ranijeg ili kasnijeg razdoblja. No, nalaza poput klinova, ulomaka posuđa, alata i slično, što bi ukazivalo na razaranje sela, nema. Stoga sam mišljenja da je uzrok promjene lokacije sela

\footnotetext{
${ }^{35}$ Nedić, Kratka povjest župe, 14.

${ }^{36}$ MKK/ŽT 1784-1803, 200/1792.

${ }^{37}$ Mato Mikić, Arkiva knjiga treća u kojoj Pověstnica iz Benića, Šipračića, Marianović i naša iz različiti knjigah i rukopisa povadjena. Catalogi Ministrorum Provlium Decreta plurima - Najposli Nota iz Protokola Kreševskog. Sve sabrano i izpisano po otcu fra Mati Mikiću, god. 1854., rukopis. Nalazi se u franjevačkom samostanu u Kraljevoj Sutjesci, POK 8, str. 72. Ambroža Vučković bio je župnikom od 1787. do 1792. godine, kada ga je zamijenio dotadašnji toliški kapelan Jakob Paradžiković. Fra Ambroža je ostao toliškim kapelanom do smrti, 27. siječnja 1802. godine, ne dočekavši uzdizanje kapelanije na razinu župe.

${ }^{38}$ Kreševljaković i Kapidžić, Vojno-geografski opis Bosne, 63: „Tolisa, Ein kristliches Dorf von etwa 15 kristlichen Häusern; so in einer von etwas hochstämmigen Waldung unterbrochenen Ebene einige 100 Schritt vom Sau Strohm liegt."

${ }^{39}$ Fotografija u: Grupa autora, Najstarija pučka škola u Bosni i Hercegovini (Tolisa 2008), 38.
} 
druge prirode; možda je riječ o izboru manje vodoplavnog područja ${ }^{40}$ a da je građevinski materijal ponovno iskorišten te ga stoga i ne nalazimo.

Bočani se, isto kao i Tolišani, nisu naselili na ono mjesto gdje su nekada živjeli, nego su podigli nove kuće oko dva kilometra sjeverozapadno od starog sela i to je bila jezgra iz koje se razvio Bok koji nam je poznat na sadašnjoj lokaciji. Kao uspomena na mjesto gdje je nekada bilo naselje ostalo je staro groblje i nedaleko od njega dio obradivog zemljišta, omeđen putom prema groblju sa sjeverne i meandrom Briježnice s južne strane, koji se zove Staro Selo te je tako upisano i na katastarskim i topografskim kartama. Selo je pomaknuto vjerojatno kako bi bilo bliže glavnoj prometnici (fra Bono kaže: „Da bude bliži prama sredotočja župe“) koja je od bogaza na Karauli vodila preko Obudovca dublje u Bosnu. Niti ovdje na lokacijama za koje tradicija govori da je bilo staro selo, izuzev jednog klina, nisam pronašao ništa od pokretnog materijala koji bi odgovarao razdoblju s kraja XVIII. stoljeća. Pretpostavljam da je tome uzrok mali broj raštrkanih kuća koje su se nalazile na prostranom terenu, te je zbog toga, bez preciznijih georadarskih ili arheoloških istraživanja, teško locirati njihov točan položaj.

Vidovice su također promijenile lokaciju, pomaknuvši se dalje od Save na jug i jugoistok, odnosno na svoj današnji prostor. ${ }^{41}$ Fra Bono piše da se i Donja Mahala pomaknula južnije od starog položaja sela, koje je bilo na mjestu koje se zove Stari šljivici. ${ }^{42}$ U Oštroj Luci postoji nekoliko verzija priče gdje je bila „stara Luka“, pa je moguće da je i ovo selo promijenilo položaj nakon povratka stanovništva. U Matićima, njive zapadno od groblja nose naziv Kućište, ali niti ovdje nema nikakvih nalaza. Postoji priča da je i Kostrč bio smješten na jednoj gredi uz Crnac, malo južnije od sadašnjeg položaja sela.

${ }^{40}$ Potvrda za ovu pretpostavku može se naći i u ljetopisu toliškog samostana: ,,... sela žitelji zadnji put povrativšise izostaviše staro mjesto gdi su jim kuće bile, što se i sad zove "Kućišta" pomakoše se dalje od rieke Tolise na malo višje ravnice radi poteškoće potopa vodenog, te se na ovom zemljištu smjestiše." Archiv, 20.

${ }^{41}$ Stari položaj Vidovica bio je, po pisanju fra Vjenceslava Tunje Janjića, na Gložnjacima, kompleksu njiva sjeverno od današnjeg vidovačkog zaseoka Albanija. Mišljenje Janjića je da su Vidovice na ovom mjestu bile do 1821. godine, a da je razlog premještanja ugroženost naselja od rijeke Save. Vjenceslav Tunjo Janjić i Ilija Orkić, Obedari (Orašje: Rkt. župni ured Svetog Vida - Vidovice, 2006), 29.

${ }^{42}$ Prema: Mijić, Vremeplov Bosanske Posavine, 127. Moguće je da je položaj ovih šljivika bio negdje oko k.č. 150, gdje sam 23. ožujka 2020. godine na površini oranice pronašao mletački novčić od 2 solda kovan u razdoblju 1691-1709. godine. 


\section{Očuvanje veza uspostavljenih u progonstvu i kolektivno sjećanje na događaj}

Poznanstva i prijateljstva uspostavljena u progonstvu nastavila su se njegovati i poslije povratka prognanika kućama. Možda najbolja ilustracija za to je životna priča Janjice Kosić, čiji je otac Anto bio u progonstvu u Tramošnici. Ona je 1812. godine ostala trudna s Nikolom Kamenjaševićem iz Tramošnice, koji ju je i oženio u studenom iste godine. Kako Nikola nije imao oca, a izgleda da je u obitelji Kosić nedostajalo radne snage, došao je živjeti u Bok kao domazet i od njega potječe današnje bočansko prezime Kamenjaš, po kojima se zove i jedan zaselak. Dijete je rođeno na drugi dan Božića, a strogi crkveni zakoni koji su tada bili na snazi primorali su pratra da dijete, koje je očito začeto prije sklapanja braka, upiše kao nezakonito (rođeno iz nedozvoljenog odnosa). Već naredne godine ovo dijete je umrlo i bio je to početak tužnog niza u kojemu su Janjica i Nikola izrodili desetak djece, od kojih su gotovo sva pomrla u jako mladoj dobi. Čini se da je Nikola bio omiljen i prihvaćen od Bočana jer je bio kumom velikom broju druge djece i svjedokom u brojnim ženidbama. U stasitoj dobi postao je članom seoskog vijeća, no umro je naglo od „nervne groznice“ u svojoj 40. godini, 12. prosinca 1829. godine. Janjica se nakon dvije godine preudala za Antu Matića, također iz Tramošnice, koji je, po svoj prilici, došao živjeti u njenu kuću.

Između Tramošnice i Boka, odnosno Matića, ima nekih poveznica i u kulturološkom pogledu. Tako imamo istu predaju o gradu carice Marije Terezije, koja se u Matićima i Boku veže za Gradić, njive na povišenoj gredi u meandru Briježnice između ova dva sela, a u Tramošnici za Gradinu, greben iznad istočnog lateralnog kanala oko kilometar udaljenosti od crkve u zaseoku Puškarići. ${ }^{43}$ Sjećanje na ovo progonstvo bilo je živo i stotinjak godina nakon njega jer bi svijet u Tolisi, kada bi pričao o nečemu što se davno desilo, rekao: „Kad je top puk'o“. ${ }^{44}$ Kroz literaturu se, kao jedan od simbola ovog progonstva, često provlači spomen nekakvog bunara koji je u Fratrovcu izgradio fra Ambroža Vučković (!), a „koga očisti, popravi i gjermom providi god. 1849. fr. Ambroža Matić radi mile uspomene svoga imenjaka“. ${ }^{45}$ Po svjedočenju fra

${ }^{43} \mathrm{Na}$ spomenutim lokacijama je, prema predaji, bio grad u kojem je boravila carica Marija Terezija. Jednog dana Turci su je opkolili, a ona je potkovala konje naopako i pobjegla. Turci su zbog tragova mislili kako je u grad stigla pomoć te su oklijevali s napadom, što je carici dalo dovoljnu prednost da umakne na sigurno. Predaju sam u Boku čuo od svog oca, Ilije Matolića (rođen 1952. god.) i brojnih drugih mještana, te je i zapisao 25. travnja 2018. godine, a u Tramošnici mi je sličnu priču ispričao i točnu lokaciju grada pokazao Petar Puškarić (rođen 1962. god.) 19. ožujka 2019. godine.

${ }^{44}$ Prema: Mijić, Vremeplov Bosanske Posavine, 126; Archiv, 19.

${ }^{45}$ Archiv, 20. 
Bone Nedića, bunar je postojao još 1887 . godine, ${ }^{46}$ a kao postojećeg ga spominje i povjesničar Pavo Živković 1973. godine, ${ }^{47}$ mada sam mišljenja da je Živković ovu tvrdnju preuzeo iz Nedićevog zapisa bez dodatnog provjeravanja. Po svjedočenju stanovnika Porebrica, u tom selu postoji jedan stari bunar koji je prije nekog skorijeg vremena i obnovljen, ali se on nalazi u zaseoku Mijatovići.

Ovaj događaj, više posredstvom literature nego usmene predaje, i danas postoji u sjećanju jednog dijela stanovnika u selima općine Orašje, dočim je u okolici Blaževca, pa čak i na samome Fratrovcu, potpuno zaboravljen. U Fratrovcu sam bio 11. srpnja 2019. godine i razgovarao s nekoliko malobrojnih mještana, pravoslavaca, koji danas tamo žive. Nitko od njih mi nije znao reći ništa o spomenutom bunaru niti o tome kako je njihov zaselak dobio ime.

\section{IZVORI I LITERATURA}

\section{NEOBJAVLJENI IZVORI:}

Archiv Samostana Franjevacah u Tolisi od Godine 1885. Knjiga I., rukopis. Nalazi se $\mathrm{u}$ franjevačkom samostanu u Tolisi. Stranice numerirane rukom 1-263.

Babić, Jakov, Bilježnica Ia: prijepis matica 1742-1784, rukopisna zaostavština. Nalazi se u franjevačkom samostanu u Tolisi. Stranice numerirane rukom 193-310.

Mikić, Mato, Arkiva knjiga treća u kojoj Pověstnica iz Benića, Šipračića, Marianović i naša iz različiti knjigah i rukopisa povadjena. Catalogi Ministrorum Provlium Decreta plurima - Najposli Nota iz Protokola Kreševskog. Sve sabrano i izpisano po otcu fra Mati Mikiću, god. 1854. Nalazi se u franjevačkom samostanu u Kraljevoj Sutjesci, POK 8.

MKK/ŽTr 1784-1805: Matica krštenih kapelanije/župe Tramošnica od 1784. do 1805. godine. Nalazi se u franjevačkom samostanu u Tolisi.

MUK/ŽTr 1784-1827: Matica umrlih kapelanije/župe Tramošnica od 1784. do 1827. godine. Nalazi se u franjevačkom samostanu u Tolisi.

MVK/ŽTr 1784-1831: Matica vjenčanih kapelanije/župe Tramošnica od 1784. do 1831. godine. Nalazi se u franjevačkom samostanu u Tolisi.

MVK/ŽT 1784-1832: Matica vjenčanih kapelanije/župe Tolisa od 1784. do 1832. godine. Nalazi se u franjevačkom samostanu u Tolisi.

\section{OBJAVLJENI IZVORI:}

Baltić, Jako, Godišnjak od događaja i promine vrimena u Bosni 1754-1882., Sarajevo-Zagreb: Synopsis, 2003.

\footnotetext{
${ }_{46}$ Nedić, Kratka povjest župe, 14.

${ }^{47}$ Grupa autora, 150 godina osnovne škole u Tolisi, 55.
} 
Mandić, Dominik, Chroati catholici Bosnae et Hercegovinae in descriptionibus annis 1743 et 1768 exaratis, Chicago-Roma, 1962.

\section{LITERATURA:}

Babić, Marko, Župa Vidovice, Vidovice-Zagreb: Fonticulus Vidovicensis i Župni ured sv. Vida - Vidovice, 2003.

Bašagić-Redžepašić, Safvet beg (Mirza Safvet), Kratka uputa u prošlost Bosne i Hercegovine (Od g. 1463. - 1850.), Sarajevo: vlastita naklada, 1900.

Grupa autora, 150 godina osnovne škole u Tolisi, Tolisa: Osnovna škola „Vladimir Nazor“ u Tolisi, 1973.

Grupa autora, Najstarija pučka škola u Bosni i Hercegovini-U spomen 185. obljetnice Osnovne škole fra Ilije Starčevića Tolisa, Tolisa: Osnovna škola fra Ilije Starčevića Tolisa, 2008.

Janjić, Vjenceslav Tunjo i Orkić Ilija, Obedari, Orašje: Rkt. župni ured Svetog Vida - Vidovice, 2006.

Kreševljaković, Hamdija i Kapidžić, Hamdija, Vojno-geografski opis Bosne pred Dubički rat od 1785. godine, Sarajevo: Naučno društvo NR Bosne i Hercegovine, Građa, Knjiga VII, Odjeljenje istorisko-filoloških nauka, Knjiga 5, 1957.

Matanović, Damir, „Sava u svakodnevnom životu krajišnika Slavonske vojne krajine“, u: Rijeka Sava u povijesti - Zbornik radova znanstvenog skupa održanog $u$ Slavonskom Brodu 18-19 listopada 2013., uredio Branko Ostajmer, Slavonski Brod: Hrvatski institut za povijest - Podružnica za povijest Slavonije, Srijema i Baranje, Slavonski Brod, Bibliotheca Croatica: Slavonica, Sirmiensia et Baranyensia, Posebna izdanja, knjiga 15, 2015., str. 251-259.

Mijić, Stanko, Vremeplov Bosanske Posavine - Crkva i samostan na Raščici, Tolisa: Franjevački samostan u Tolisi, 2002.

Mikičić, Mato, Oštra Luka i Bok do početka Domovinskog rata 1992., Oštra Luka, 1994.

Nedić, Bono, Kratka povjest župe, crkve i samostana toliškog, uz pripomoć rukopisah velečastnog o. Martina Nedić-a sastavijo i na svijetlo izdao o. fra Bono Nedić župnik brčanski, Pečuh: Tiskara Mihajla Talzsa, 1887.

Šljivo, Galib, Bosna i Hercegovina 1788-1812, Banjaluka: Institut za istoriju u Banjaluci, Studije i monografije, knjiga 7, 1992. 


\author{
Summary \\ THE CATHOLIC POPULATION OF THE VILLAGES OF \\ THE CHAPLAINCY OF TOLISA DURING THE TIME OF THE \\ DUBICA WAR (1788-1791)
}

The last war in history fought between Austria and the Ottoman Empire is known as the "Dubica War" (1788-1791), and although the military actions were limited to a narrow area, this war had strong consequences for the population of the Catholic chaplaincyof Tolisa. The Turkish authorities, anxious to secure the cooperation of Catholics living on the banks of the Sava River, decided to systematically relocate those who had established their houses south of the river. War was officially declared on February 9, 1788 and in the following month around 1,600 inhabitants, as many as lived in the chaplaincy at the time, were relocated to the villages of the Dubrava parish and the chaplaincy of Tramošnica, particularly in the area between Blaževac and Porebrica where the new village Fratrovac was established, named after a friar who had settled there with his people. The newcomers to the area were accepted in a friendly manner by the local population and adapted well to the new environment. Until the return to their villages in August 1791, 223 children were born and 110 people died in exile. After their return to Posavina, some of the villages, such as Tolisa, Boka and Vidovica were not established at the former locations; the returnees chose new locations which became the centres from which the above villages as we know them today emerged.

Keywords: Dubica War, Bosnian Posavina, relocation, Tolisa, Fratrovac, population

\title{
Kontakt autora:
}

Marko Matolić, prof.

Orašje, Bosna i Hercegovina

E-mail: sarhosmrakan@gmail.com 